\title{
Research and development in foreign affiliates : evidence from Japanese firms
}

Citation for published version (APA):

Belderbos, R. A., \& Iwasa, T. (1999). Research and development in foreign affiliates : evidence from Japanese firms. NIBOR, Netherlands Institute of Business Organization and Strategy Research. NIBOR Research Memorandum No. 05 https://doi.org/10.26481/umanib.1999005

Document status and date:

Published: 01/01/1999

DOI:

10.26481/umanib.1999005

Document Version:

Publisher's PDF, also known as Version of record

\section{Please check the document version of this publication:}

- A submitted manuscript is the version of the article upon submission and before peer-review. There can be important differences between the submitted version and the official published version of record.

People interested in the research are advised to contact the author for the final version of the publication, or visit the DOI to the publisher's website.

- The final author version and the galley proof are versions of the publication after peer review.

- The final published version features the final layout of the paper including the volume, issue and page numbers.

Link to publication

\footnotetext{
General rights rights.

- You may freely distribute the URL identifying the publication in the public portal. please follow below link for the End User Agreement:

www.umlib.nl/taverne-license

Take down policy

If you believe that this document breaches copyright please contact us at:

repository@maastrichtuniversity.nl

providing details and we will investigate your claim.
}

Copyright and moral rights for the publications made accessible in the public portal are retained by the authors and/or other copyright owners and it is a condition of accessing publications that users recognise and abide by the legal requirements associated with these

- Users may download and print one copy of any publication from the public portal for the purpose of private study or research.

- You may not further distribute the material or use it for any profit-making activity or commercial gain

If the publication is distributed under the terms of Article $25 \mathrm{fa}$ of the Dutch Copyright Act, indicated by the "Taverne" license above, 


\title{
Research and Development in Foreign Affiliates: Evidence from Japanese Firms
}

\author{
NIBOR/RM/99/05 \\ René Belderbos, Maastricht University \\ Tomoko Iwasa, Hitotsubashi University
}

Faculty of Economics and Business Administration

NIBOR (Netherlands Institute of Business Organization and Strategy Research)

\author{
Maastricht University \\ Department of Management Science \\ P.O. Box 616 \\ 6200 MD Maastricht \\ The Netherlands \\ Telephone: +31433883806 \\ Facsimile: +31433258495 \\ Email: r.belderbos@mw.unimaas.nl
}

\begin{abstract}
ACKNOWLEDGEMENTS
This research was conducted in liaison with the Institute of International Trade and Investment in Tokyo. We thank the Institute for preparing and processing the data. We are also grateful to the Science Policy Research Unit at the University of Sussex and the Institute of Innovation Research at Hitotsubashi University for provision of research support. Rene Belderbos' research is funded by the Royal Dutch Academy of Arts and Sciences. We thank Geert Duysters, Peter Holmes, Barry Reilly, Mariko Sakakibara, Wim Vanhaverbeke, and participants at seminars at Maastricht University and the University of California at Davis for helpful comments.
\end{abstract}




\title{
Research and Development in Foreign Affiliates: Evidence from Japanese Firms
}

\begin{abstract}
This paper analyzes the determinants of the R\&D intensity of 434 foreign affiliates, drawing on MITI's benchmark survey of Japanese multinational firms in 1993. Acquired affiliates are responsible for more than half of overseas $R \& D$ expenditure and have significantly higher R\&D intensities than wholly and majority owned greenfield affiliates. Non-majority owned joint ventures are $R \& D$ intensive in case the investing firm lacks substantial $R \& D$ capabilities in Japan. In contrast, $R \& D$ intensive Japanese parent firms prefer controlled modes of overseas R\&D investment. Support is also found for an incremental growth pattern of foreign R\&D operations as a function of cumulative learning. This learning is affiliatespecific rather than firm-wide and applies to greenfield affiliates but not to acquired affiliates. The results provide evidence that Japanese multinational firms, as 'latecomers' in the establishment of overseas R\&D networks, have often made use of acquisitions and collaborative ventures to gain access to overseas technology and to establish overseas R\&D capabilities at a faster pace.
\end{abstract}




\section{Research and Development in Foreign Affiliates: Evidence from Japanese Firms}

\section{INTRODUCTION}

Research and Development (R\&D) has long been regarded the functional activity that multinational firms were only likely to transfer abroad in the last stages of their internationalization. In product cycle theory, overseas $R \& D$ is motivated by the need to adopt and adapt products and production processes to local markets and resource conditions [Vernon (1979)]. Foreign R\&D follows the expansion of overseas marketing and manufacturing activity with some lag and focuses on local improvements of relatively mature technologies developed in home country laboratories. Closely related to the product cycle concept is the notion of an evolution in the tasks and responsibilities of overseas R\&D sites, which are seen to take on more sophisticated roles over time. As foreign sites build up experience and establish credibility as competent and reliable adaptors of technologies, they may be assigned more complex tasks such as developing new products for local and regional markets [DeMeyer (1997), Hewitt (1980), Ronstadt (1997)].

More recent analysis of the internationalization of R\&D by multinational firms has suggested that foreign $R \& D$ sites are increasingly assigned the role of creators of basic technologies and developers of completely new products for world markets [Pearce and Singh (1991), Florida (1997), Kuemmerle (1997)]. Due to a shortening of product life cycles, increased global competition, and rapid technological developments, multinational firms need to 'tap into' centers of world excellence in given technological fields [Bartlett and Ghoshal (1989)]. The driving motivation is access to technology, know how, and leading scientists and researchers, if these are not readily available in the home country. The challenge is to utilize technological learning in geographically dispersed sites by communicating and integrating it into the firm's global organization. This is the subject of an emerging literature on coordination and control processes in international $R \& D$ and the relationship with $R \& D$ performance. [Brockdorf and Schmaul (1996), DeMeyer (1997), DeMeyer and Mizushima (1989), Florida (1997), Ghoshal and Bartlett (1988)].

The notion of a growing role of foreign technology creation activities by multinational firms implies a rise in the level of foreign $R \& D$. Whether a substantial increase in the internationalization of $R \& D$ has actually been occurring over the last decade is still a rather 
contentious issue, with conflicting evidence pointing to a rather stable share of overseas $R \& D$ activities [Pavitt and Patel (1991), Patel (1995)], versus growth [Hakanson and Nobel (1993a, 1993b), Kuemmerle (1997), Gerybadze and Reger (1999)]. One undisputed finding is that Japanese multinational firms distinguish themselves from European and American firms by a particular reluctance to internationalize their R\&D. In the late 1980s, a mere 1 percent of US patent grants to the 139 largest Japanese industrial multinational firms was based on research performed in overseas laboratories. This compared to 8 percent for US multinationals and 4060 percent for European multinationals [Patel (1995)]. Japanese firms have also traditionally shown a preference to maintain tight control over existing overseas development units [Gassmann and von Zedtwitz (1999), Cheng and Bolon (1993), Behrman and Fischer (1980), Bartlett and Ghoshal (1991), Ghoshal ad Bartlett (1988)]. It has been suggested that centralization of R\&D in Japan is a consequence of the Japanese system of innovation characterized by intensive coordination and communication between $\mathrm{R} \& \mathrm{D}$, marketing, and manufacturing as well as collaboration with suppliers [Odagiri and Yasuda (1996), Odagiri and Goto (1993)]. A strong geographical concentration of manufacturing, applied R\&D, and engineering facilities in Japan fosters such intensive communication and personnel rotation [Kenney and Florida (1994), Westney (1994)]. Newly developed products are test manufactured in Japanese pilot plants [Fruin (1992)] and first sold on the sophisticated and quality conscious Japanese market, which provides stimulus for continuous improvement [Porter (1980)]. The strong integration of R\&D with other functions of the firm is considered one of the factors behind the rise in Japanese firms' technological capabilities and global competitiveness [e.g. Freeman (1987), Wakasugi (1992)]. This system implies a relatively strong concentration of $\mathrm{R} \& \mathrm{D}$ activities in Japan, and a centralized control over overseas development units. Case study evidence has suggested that such centralized management of R\&D can perform well provided that the firm allows for sufficient input by overseas affiliates into the innovation process. ${ }^{1}$

On the other hand, an alternative explanation of the low degree of Japanese firms' R\&D internationalization could be given by Japanese firms' late rise as substantial investors in manufacturing activities abroad after 1985. Japanese affiliates abroad have had less time to develop strong R\&D capabilities and to evolve into more sophisticated sites. R\&D activities abroad may expand more rapidly after the firms have learned how to operate a network of dispersed manufacturing and R\&D facilities abroad. There is some evidence suggesting an increasing emphasis on foreign $R \& D$ and a declining role of centralized $R \& D$ management. A number of studies have found that a relatively rapid pace of foreign R\&D growth by 
Japanese firms in the early 1990s, albeit from a very low base [Belderbos (1999), Grandstrand (1999), Gerybadze and Reger (1999), Papanastassiou and Pearce (1994)]. Florida (1997), in a recent study of foreign owned research laboratories in the United States, found very little evidence that Japanese firms relied on coordinated control of overseas research sites. Japanese research laboratories in the United States operated with substantial autonomy and adopted a US managerial style rather than a traditional Japanese R\&D management orientation.

If Japanese firms are targeting a more decentralized and internationalized organization of $R \& D$ activities, an important issue is how they intend to reach this goal. Here evidence is emerging that Japanese firms have since the late 1980s reduced their reliance on internal growth and shifted emphasis on joint ventures with foreign partners and acquisitions of R\&D intensive foreign firms. Penner-Hahn (1998) suggests that the time pressure faced by late Japanese entrants into the pharmaceutical industry resulted in a preference for collaborative overseas $R \& D$ rather than a sequence of international operations starting with sponsoring research at foreign universities. Belderbos (1999) found evidence of an important role of foreign acquisitions. More than 40 percent of overseas innovations patented in the US during 1989-1993 by a large sample of Japanese electrical engineering and electronics firms originated from research in acquired companies. Grandstrand (1999) reports that R\&D managers in large Japanese multinationals perceive their strategy with respect to the creation of technological capabilities to rely relatively strongly on acquisitions, joint ventures and collaboration with foreign universities.

The above suggests that a more systematic analysis of the characteristics of foreign R\&D by Japanese firms may provide important insights into the importance of organizational learning as well as entry strategy in the process of R\&D internationalization by latecomer firms. In this paper we contribute by a statistical analysis of the determinants of $R \& D$ expenditures in a large sample of Japanese overseas affiliates active across manufacturing industries. We utilize unpublished data on 434 Japanese affiliates derived from MITI's Basic Survey on Foreign Investment for the fiscal year ending March 1993. Specifically, we test whether there is evidence of an evolutionary growth of $\mathrm{R} \& \mathrm{D}$ activities and whether there are systematic differences in the R\&D intensity of these affiliates in relation to ownership and establishment mode. We employ a large set of controls for locational, industry, and other affiliate and parent firm characteristics.

This paper is the first to analyze affiliate level data on R\&D expenditure for a large sample of Japanese firms. As noted in surveys by Cheng and Bolon (1992) and Grandstrand 
et al. (1993), unavailability of data has kept the number of desaggregated studies extremely limited. Most previous studies of overseas R\&D expenditure [e.g. Hirschey and Caves (1981), Lall (1979), Hewitt (1980), Kumar (1996)] substituted the industry for the firm. ${ }^{2}$ Later studies have examined R\&D internationalization at the parent firm level [e.g. Pearce (1989), Odagiri and Yasuda (1996), Belderbos (1999)]. Although studies of the management of overseas $R \& D$ have by their nature focused on the organization within $R \& D$ performing affiliates [Ghoshal and Bartlett (1988), Nobel and Birkinshaw (1998), Florida (1997)], to date only a few studies of Swedish multinational firms [Zejan (1990), Hakanson and Nobel (1993a, 1993b), Fors (1996)] have systematically examined the determinants of overseas $\mathrm{R} \& \mathrm{D}$ expenditures at this level. ${ }^{3}$

The remainder of this paper is organized as follows. In the next section we provide an overview of the relevant literature and develop hypotheses concerning the determinants of the R\&D intensity of overseas affiliates. Section 3 describes the methodology and provides descriptive statistics. Section 4 presents the statistical results and Section 5 discusses the results and Section 6 concludes.

\section{THE DETERMINANTS OF THE R\&D INTENSITY OF FOREIGN AFFILIATES: BACKGROUND AND HYPOTHESES.}

The literature on $R \& D$ internationalization has established a number of factors impacting on the size and characteristics of foreign R\&D activities. ${ }^{4}$ In this section we give a brief overview of the previous literature which serves as the framework for our hypotheses concerning the determinants of the R\&D intensity of foreign affiliates

\subsection{BACKGROUND}

There is broad consensus in the literature that overseas $R \& D$ is determined as a balance between a number of centripetal factors favoring centralization at home and centrifugal factors favoring geographical dispersion [e.g. Pearce (1989)]. A major factor keeping $R \& D$ at home are the economies of scale and scope associated with $R \& D$ and in particular (basic) research. The high cost of dedicated laboratory and testing equipment, for instance, favors centralization of activities in one location. The scale and scope advantages of large home laboratories are important for 'science based' industries such as chemicals and 
electronics, in which innovations rely on basic R\&D and basic scientific progress [e.g. Patel and Pavitt (1990)]. Since research is an inherently uncertain process and firms need to master a variety of technologies to develop new products, close interaction between researchers with different areas of expertise is required. The optimal scale of foreign laboratories is found to be around 250 employees, but the scale of domestic central research laboratories may exceed 1000 employees [Perrino and Tipping (1991), Kuemmerle (1998)]. Another factor disfavoring dispersion of $R \& D$ is the cost of communication within and coordination of a network of overseas $R \& D$ sites, which can be prohibitive in particular when overseas sites are to take on more sophisticated roles in research [DeMeyer (1997), DeMeyer and Mizushima 1989)]. ${ }^{5}$ Firms furthermore have a preference to keep strategic R\&D activities at home in close connection with headquarters since dispersion of R\&D activity increases the risk that proprietary knowledge unwillingly spills over to foreign firms and institutions. All these factors weigh most heavily if the firm's has a history of centralized control. Firms with a basic attitude towards centralization face greater difficulties in setting up and managing decentralized R\&D sites and are less likely to delegate substantial research responsibilities to foreign R\&D sites [DeMeyer and Mizushima (1989)].

Centrifugal factors promoting geographical dispersion of $R \& D$ relate to the two basic motivations for the internationalization of R\&D: exploitation of the firm's technology abroad (adoption and adaptation of technologies) and access to overseas technology and know how (creation of technologies). ${ }^{6}$ The first motivation relates to the product cycle and evolutionary perspective on $R \& D$ and suggests that foreign $R \& D$ follows the internationalization of sales and manufacturing. The maturity of the products as well as the international experience of the firm are expected to be positively related to foreign $R \& D$. The second motivation suggests that foreign $R \& D$ is attracted to locations where specific scientific and industrial know-how is concentrated. By locating in such areas, firms attempt to benefit from R\&D spillovers, which are found to be largely local or regional in nature [e.g. Almeida (1996), Jaffe et al. (1993)]. The different motivations for foreign R\&D lead to different corresponding roles for overseas $R \& D$ sites. In a review of the literature on this subject, Nobel and Birkinshaw (1998) distinguish three main types of sites. 'Local adaptor' sites adapt products and processes to local demand and manufacturing conditions, 'international adaptor' sites have a more elaborate role and also develop improved products for local and other foreign markets, and 'international creator' sites are R\&D leaders in their area of expertise and provide crucial inputs to the firm's overall R\&D program. The latter role corresponds to the technology access motivation and the former roles to the technology exploitation motivation. 
Empirical studies on the determinants of overseas R\&D have tested various hypotheses based on the distinction between centrifugal and centripetal factors and generally confirmed the empirical relevance of this analytical framework. A common finding is that foreign R\&D increases with the level of overseas sales and overseas manufacturing activity, and with the degree of international experience, consistent with the technology exploitation hypothesis and the notion of evolutionary growth in overseas R\&D. Across locations, R\&D is higher in countries and regions with higher R\&D expenditure relative to GDP [Kumar (1996), Hakanson (1992), Fors (1998)], which is in line with the access to technology hypothesis. There is also evidence that the most $R \& D$ intensive industries spend less on $R \& D$ abroad relative to their domestic R\&D spending, confirming that centripetal forces are relatively more important for research based industries [e.g. Hirschey and Caves (1981), Patel (1996)].

Comparative analysis of Japanese, European, and US multinational firms has shown that Japanese firms do systematically less R\&D abroad, [Pearce and Singh (1990), Patel (1996)] and operate much more recently established, smaller scale, research laboratories [Kuemmerle (1999)]. On the other hand, the underlying determinants of Japanese R\&D abroad are found to conform to those relevant to other multinational firms. For instance, Odagiri and Yasuda (1996) confirmed that overseas R\&D at the industry and parent firm level increases with the level of overseas sales and manufacturing. Belderbos (1997, 1999) found that Japanese firms that had set up their first overseas greenfield manufacturing affiliates relatively late had significantly smaller overseas $R \& D$ activities, consistent with an important role for internationalization experience in operating overseas R\&D networks.

\subsection{HYPOTHESES}

Connecting to the literature described above, we develop hypotheses concerning the determinants of the R\&D intensity of Japanese affiliates abroad.

Case studies have suggested that firms with a basic attitude towards centralization face greater difficulties in setting up and managing decentralized R\&D sites and are less likely to delegate substantial research responsibilities to foreign R\&D sites [DeMeyer and Mizushima (1989), Cheng and Bolon (1993)]. Such differences in managerial practice that are part of the 'administrative heritage' [(Bartlett and Ghoshal (1989)] of a firm are difficult to capture and quantify. A reasonable conjecture is that a strong tradition of centralized 
management also makes coordination of a network of dispersed manufacturing facilities more difficult and costly. ${ }^{7}$ Hence, the attitude towards centralization is likely to be reflected in a lower level of internationalization of production.

Hypothesis 1: Firms with a stronger tradition of centralized management internationalize their manufacturing operations less and assign less $R \& D$ responsibilities to overseas affiliates.

Besides the degree of manufacturing internationalization and management centralization, the history of the firm's internationalization matters. Firm that have been relatively early in setting up extensive manufacturing operations abroad have accumulated experience in operating overseas manufacturing plants and coordinating international operations. Such experience will allow the firm to establish and improve the necessary coordination and control systems facilitating the growth of foreign R\&D [Grandstrand, Hakanson and Sjölander (19993), Zejan (1990)].

Hypothesis 2: Firms with a longer history of operating overseas manufacturing plants have accumulated more experience in coordination and control of a dispersed network of affiliates and are able to assign greater $R \& D$ responsibilities to overseas affiliates.

Experience at the affiliate level also affects $R \& D$ responsibilities and $R \& D$ intensity. In the evolutionary perspective on overseas $R \& D$, affiliates that have been operating longer are more likely to have been given $R \& D$ responsibilities and to have established themselves as reliable factor in the firm's manufacturing and R\&D network. A limited number of previous studies have obtained positive and significant effects of operating experience on affiliate R\&D [Belderbos (1997), Hakanson and Nobel (1993a, 1993b)]. ${ }^{8}$ However, whereas the evolutionary perspective clearly relates to internal growth and the establishment of greenfield operations only, most studies have failed to make a distinction between experience in greenfield affiliates and acquired affiliates. The link between experience and R\&D intensity is severed if the affiliate has existing technological capabilities and R\&D operations when it comes under foreign control. The years after acquisitions under foreign control may involve efforts to integrate $R \& D$ operations into the existing network of the parent firm. This could lead to a reorganization of $R \& D$ operations and even a reduction in $R \& D$ where it duplicates existing work or does not fit into the R\&D strategy of the acquiring firm [e.g. 
Hakanson (1995), Belderbos (1999)]. There is mixed empirical evidence on post-acquisition developments in R\&D spending. Hitt et al. (1991) found a post-acquisition reduction in R\&D intensity for merged groups and argued that acquisitions and R\&D investment may be seen as substitutes by managers of the acquiring firms. Hall (1988) on the other hand found no such effect in a large sample of acquisitions in the US. Belderbos (1999) found evidence of a reduction in patent output in affiliates acquired by Japanese firms and attributed this to difficulties in retaining key $\mathrm{R} \& \mathrm{D}$ personnel after the change in ownership and management.

Hypothesis 3: Among greenfield affiliates, accumulated operating experience is associated with higher R\&D intensity; among acquired affiliates operating experience under foreign ownership has a neutral or negative impact on $R \& D$ intensity.

The establishment mode of the affiliate (greenfield vs. acquisition) is hypothesized to have a major impact on $R \& D$ intensity. If acquired affiliates have an existing $R \& D$ capability, the affiliate does not have to go through the painstaking process of incrementally building up $R \& D$ capabilities. Acquired affiliates therefore are likely to be more $R \& D$ intensive compared with greenfield affiliates at the time of investment. Moreover, the R\&D intensity of acquired affiliates is expected to be particularly high relative to the $R \& D$ intensity of greenfield affiliates if the main purpose of the acquisition is to access and utilize the affiliate's R\&D capability and its links with the local system of innovation. There is evidence that access to technology is an important motivation for international acquisitions [Chakrabarti et al. (1994)], and of frequent post-acquisitions redeployment of R\&D resources from target to acquirer as well as from acquirer to target [Capron et al. (1998)]. Earlier empirical studies have shown that a major part of overseas R\&D expansion by Swedish and Japanese firms (the latter since the late 1980s) has been due to acquisitions [Grandstrand and Sjölander (1990), Belderbos (1999)]. There is also evidence for Swedish and Japanese firms that acquired foreign affiliates are more $R \& D$ intensive than greenfield affiliates [Hakanson and Nobel (1993a), Belderbos (1997]. These studies have not made a distinction between minority stake acquisitions and acquisition of majority control. On the one hand, majority stake acquisitions will give the acquiring firm the leverage to coordinate and integrate the existing R\&D operations, and without this the benefits of $R \& D$ intensive acquisitions may be limited. On the other hand, a minority stake may be sufficient to give the acquiring firm access to the technology developed by the foreign firm. For instance, in the electronics and biotechnology industries it is often observed that large multinationals take minority stakes in 
a range of highly $R \& D$ intensive pioneering firms to gain preferential access to new technologies [Wortmann (1990), Belderbos (1997)].

Hypothesis 4: Acquired affiliates have higher R\&D intensities than greenfield affiliates, in particular if the primary motivation for the acquisitions is to gain access to technology. This holds for both minority stake and majority stake acquisitions.

Although a rich body of literature has developed on strategic alliances in $R \& D$ and research joint ventures [e.g. Duysters and Hagedoorn (1996), Vonortas (1997)], the literature on the determinants and management of international R\&D has not paid much attention to the role of joint ventures. At the same time, a large number of empirical studies of the choice between the establishment of joint ventures and wholly owned affiliates have shown an important role for R\&D intensity and technology transfer [e.g. Gomes Cassares (1989), Gatignon and Anderson 1988), Mutinelli and Piscitello (1988), Hennart (1991)]. The latter studies have tested - in most cases successfully- the hypothesis based on transaction cost theory that firms with substantial $R \& D$ capabilities planning to transfer technology to foreign ventures are more likely to choose to establish wholly owned affiliates rather than joint ventures, and in particular non-majority controlled ventures. Controlled ventures are preferred because of the risk of opportunism on the side of the foreign partner and the potential loss of proprietary technology in case technology is transferred to joint ventures. Ramachandran (1993) in a study of technology transfer to ventures in India found further evidence that the level of such transfers is less in partially owned firms than in wholly owned affiliates. The empirical studies on ownership structure have also shown a negative impact of $R \& D$ intensity in the host country industry on the likelihood that affiliates are established as wholly owned ventures. In case the local industry is R\&D intensive, access to local know how and technology is more likely to be an important motivation for the foreign venture. Access to local technologies, in particular if it resides in the local partner firm, is best obtained through the establishment of a joint venture. If the foreign partner has a technological advantage it is also more likely to demand a stronger control in the venture, and the venture is less likely to be majority owned by the foreign firm.

The above line of reasoning has direct but so far yet untested consequences for the $R \& D$ intensity of foreign affiliates. In general, even if the goal of the joint venture is limited to joint marketing and manufacturing, the joint venture may rely on the expertise and existing resources of the local partner to adapt products and processes to local conditions faster. This 
is likely to involve moderately higher levels of R\&D effort in both majority owned and nonmajority owned joint ventures. The establishment of $R \& D$ intensive joint ventures is most advantageous for firms that lack important $R \& D$ capabilities themselves and that want to get access to, and build on, the know how of the foreign partner. In that case, as indicated above, the Japanese firm is less likely to have a majority stake. There is some evidence that technology sourcing has indeed been a motive for Japanese joint ventures abroad, but no specific attention has been given to the ownership level of such ventures. For instance, Kogut and Chang (1991)] found that Japanese firms set up joint ventures more frequently in those US industries that are more R\&D intensive than the comparable industries in Japan. PennerHahn (1998) found that in particular latecoming Japanese entrants into the pharmaceutical industry had a preference for collaborative overseas $R \& D$ in order to build up $R \& D$ capabilities faster. ${ }^{9}$ Transaction cost theory suggests that such technology sourcing is much less likely to be a motivation for non-majority controlled joined ventures established by R\&D intensive investors with leading technological capabilities. The need for technology sourcing is less and technology transfer to the ventures may run the risk of unwanted dissipation of proprietary technology. The high transaction costs associated with joint ventures in this case give strong incentives to concentrate overseas $R \& D$ in controlled ventures. Hence, if $R \& D$ intensive parent firms establish non-majority controlled affiliates, these affiliates are most likely to be less R\&D intensive.

Hypothesis 5: Majority owned joint ventures have moderately higher $R \& D$ intensities compared with wholly owned subsidiaries. Non-Majority controlled joint ventures have substantially higher $R \& D$ intensities in case the investing parent firm has limited $R \& D$ capabilities, but lower $R \& D$ intensities if the investing firm has strong $R \& D$ capabilities.

Previous research has established a positive effect of the export intensity of affiliates on the scale of R\&D activities [Zejan (1990), Hirschey and Caves (1981), Hewitt (1980)]. High export intensities often imply that the affiliates have responsibility for regional or world markets in a product area rather than a more limited responsibility for the local market. Such affiliates are more likely to have developed $R \& D$ expertise which allows them to function as 'international adaptor' sites or even as 'international creator' sites [Nobel and Birkinshaw (1998), Hakanson and Nobel (1993b)]. International adaptor and creator sites typically have greater R\&D responsibilities and higher R\&D intensities than 'local adaptor' sites associated with a local sales orientation. 
Hypothesis 6: Export intensive affiliates have greater $R \& D$ responsibilities and higher $R \& D$ intensities.

\section{METHODOLOGY AND DATA}

\subsection{DATA}

We draw data from the Fifth Basic Survey on Foreign Investment, an extensive survey among Japanese multinational firms held every three years by the Japanese Ministry of International Trade and Industry [MITI (1994)]. The survey received responses by 846 parent firms active in manufacturing industries, of which 658 firms operated at least one foreign manufacturing affiliate abroad. These 658 firms operated 2030 foreign manufacturing affiliates among them. Affiliates are included in the survey if the Japanese firm owns at least 10 percent of equity. ${ }^{10}$ Although firms are asked to enter a value for R\&D expenditures for each affiliate, the response rate for this question is relatively low, reducing the sample of affiliates available for analysis. ${ }^{11}$ Excluding further the affiliates for which information on the independent variables (entry mode, exports, parent firm R\&D expenditure, etc) was not available resulted in a sample of 434 affiliates owned by 206 parent firms. The total R\&D expenditure of the 434 affiliates was 30.4 billion Yen (about 250 million US dollars in 1992 exchange rates), out of a total foreign $\mathrm{R} \& \mathrm{D}$ expenditure of 52.9 billion Yen recorded in the MITI survey for all manufacturing firms. Of the 434 affiliates, 218 reported zero R\&D expenditure.

The affiliates are distributed over industries and regions in a similar manner as the total population of affiliates. ${ }^{12}$ Table 1 shows the distribution over industries, regions, and mode of entry and ownership. The electronics and electrical engineering industry is divided into the less technology intensive segments electrical machinery and home electrical appliances, and the more technology intensive segments computers and telecommunication equipment, audio and video equipment, other electronic equipment, and parts and components. After this subdivision, the largest number of affiliates is present in the transport machinery industry (73), followed by the chemical industry (52), the metal industry (43), and general machinery (41). The average (unweighted) R\&D intensity of the 434 affiliates is 0.85 percent. The R\&D intensity is highest in the pharmaceutical industry, the rubber and tire industry, and computers and telecommunications, precision machinery, and electronic equipment. ${ }^{13}$ The rubber and tire industry also has the largest absolute expenditure on foreign 
$R \& D$ (almost a quarter of total R\&D expenditure in the sample) followed by computers and telecommunications and the transport machinery industry. The lowest R\&D intensities are found in electrical machinery, building materials, and textiles. The regional distribution of affiliates shows that more than hundred affiliates are located each in the Newly Industrialized Economies in Asia (NIEs), North America, and ASEAN countries and China. In Western Europe and other countries less than fifty affiliates are located. Although more than half of total $R \& D$ expenditure takes place in North America, the average $R \& D$ intensity of North American affiliates is surpassed by European affiliates (1.70 vs. 1.39 percent). Least R\&D intensive are affiliates in ASEAN countries and China and R\&D expenditure in these countries only makes up less than two percent of the total. The distribution of affiliates across entry mode and ownership shows that about a third (148) of the affiliates are newly established and wholly owned. Joint ventures are more numerous with 89 affiliates majority owned and 103 affiliates with shared or minority ownership. Joint ventures have a slightly lower R\&D intensity on average than wholly owned affiliates. The figures on $R \& D$ expenditure provide evidence for a major role for acquisitions in the expansion of foreign R\&D by Japanese firms: majority and minority acquisitions are responsible for 39 and 17 percent of total R\&D expenditure, respectively. Acquired affiliates also have the highest average R\&D intensity at 2.15 percent, followed by minority stake acquisitions (1.04 percent). We note, however, that one should be careful in drawing inferences from these unidimensional tabulations. Differences in R\&D intensities across countries, for instance, are also determined by differences in industry mix of affiliates, the inclusion of acquisitions, etc. Only with multivariate analysis such as the analysis reported in the next sections can we gain more insight in the various factors affecting $R \& D$ intensities. The results will in a number of cases contrast with the simple inferences that one may be inclined to draw from Table 1 on the relationship between R\&D intensity on the one hand, and industry, location, and entry mode and ownership on the other.

\subsection{METHODOLOGY AND DEFINITION OF VARIABLES}

Since the dependent variable, $R \& D$ intensity, is censored on the left-hand side at zero, ordinary least squares analysis gives inconsistent estimates [Greene (1997)]. We therefore use 
a censored regression (Tobit) model to relate the dependent variable $R \& D I N T_{i}$ of affiliate $i$ to a vector of regressors $x_{i}$. We define a latent underlying regression as:

$$
R \& D I N T_{i}^{*}=\beta^{\prime} x_{i}+\varepsilon_{i}
$$

where $\beta$ are the estimated coefficients and $\varepsilon_{i}$ is a normally distributed error term. We observe:

$$
\begin{aligned}
& R \& D I N T_{i}=0 \quad \forall R \& D I N T_{i}^{*} \leq 0 \\
& R \& D I N T_{i}=R \& D I N T_{i}^{*} \forall R \& D I N T_{i}^{*}>0
\end{aligned}
$$

The estimated coefficients are marginal effects of the latent regression and larger than the marginal effects of the regressors on the observed variable $R D I N T_{i}$. To obtain the relevant marginal effects, we have to multiply $\beta$ with the probability of non-censoring: $\beta\left[\operatorname{prob}\left(R D I N T_{i}^{*}>0\right)\right] .^{14}$

We test the hypotheses developed in Section 2 by including a number of determinants both at the affiliate and the parent firm level, while employing a set of controls for industry and locational characteristics. The determinants and controls described by the vector $x_{i}$ are constructed from the information available in the MITI survey. Table 2 gives a description of the variables with their means and standard deviations (a table with correlation coefficients is relegated to the appendix).

Hypothesis 1 suggests a positive correlation between the degree of manufacturing internationalization and the $R \& D$ intensity of manufacturing affiliates. The difficulty in obtaining a direct measure of firms' attitudes towards centralization precludes a direct test of the complete hypothesis. An indirect test of the hypothesis is possible by including the variable P_FDI, the assets of all foreign manufacturing affiliates operated by the firm as a percentage of the assets of the parent firm in Japan. Hypothesis 1 predicts a positive sign. Hypothesis 2 is tested by including the variable P_EXPE, the log of the number of years since the parent firm established its first manufacturing subsidiary abroad. A positive sign is expected. We test Hypothesis 3 by including two variables to capture affiliate level experience effects: $\operatorname{EXPE}(\mathrm{GR})$ is the log of the number of years since the start of operations for greenfield affiliates, and $\operatorname{EXPE}(\mathrm{ACQ})$ is $\log$ of the number of years since acquisition for acquired affiliates. ${ }^{15} \mathrm{EXPE}(\mathrm{GR})$ is expected to be positive while the sign of $\operatorname{EXPE}(\mathrm{ACQ})$ is not a priori determined. To test hypothesis 4 we include a dummy variable, ACQ(MAJ), 
which takes the value one if the affiliate came under the control of the Japanese parent through an acquisition and if the affiliate was majority owned in 1993. In addition, ACQ(MIN) takes the value one if the Japanese firms acquired a stake in an existing foreign firm but did not have majority control in 1993. Both ACQ(MAJ) and ACQ(MIN) are expected to have a positive sign, but we do not have a strong prior concerning the relative magnitude of the two coefficients. Although we cannot test the effect of motivation on R\&D in the absence of an indicator of acquisition motivations in our dataset, a large positive effect of the acquisition dummies will suggest an underlying technology sourcing motive. Hypothesis 5 is tested by including a dummy variable, JV(MIN), for non-majority owned joint ventures (ventures in which the Japanese investor had a 50 percent stake or less in 1993). We expect a positive effect of JV(MIN) but contingent on the R\&D intensity of the parent firm. Hence we include the cross term of the R\&D intensity of the parent firm in Japan (P_R\&D)xJV(MIN) and expect a negative coefficient. Hypothesis 5 also suggests that the combined effect of $P_{-}$R\&DxJV(MIN) and JV(MIN) is negative for the most R\&D intensive parent firms. Finally, Hypothesis 6 suggests that the variable EXPORT, the ratio of export over sales of the affiliate, has a positive sign.

We include an elaborate set of control variables. At the parent firm level, the R\&D intensity of the investing firm may have an impact on the R\&D intensity of foreign affiliates. If the parent firm produces technologically complex products and relies heavily on R\&D, this will also be reflected in the R\&D intensity of affiliate operations. Belderbos (1997) and Zejan (1990) found a positive correlation between affiliate and parent firm R\&D intensities and Odagiri and Yasuda (1996) found such a relationship at the industry level. We include the $R \& D$ to sales ratio of parent firm operations in Japan (P_R\&D). We also control for the size of the affiliate. A certain level of sales may be required to justify investments in development for the local market, and scale economies in research may favor R\&D in larger affiliates. Larger affiliates may also be better able to bargain with headquarters about allocation of $R \& D$ resources. The evidence on the effect of size on R\&D intensity is mixed. Kumar (1996) and Zejan (1990) found weakly significant positive effects of affiliate size on R\&D intensity, but results in Odagiri and Yasuda (1996) and Belderbos (1997) suggested that R\&D expenditures increase proportionally with affiliate sales. The industrial organization literature on the relationship between firm size and R\&D investment has also by and large failed to find evidence that larger firms are more R\&D intensive [Cohen and Klepper (1996)]. In order to control for possible scale effects, we include the variable SIZE (sales of the affiliate). Another characteristic of affiliates that may affect $R \& D$ intensity is the reliance on imported 
components and materials as well as imported final goods. Affiliates that have a more accentuated role as a distributor and assembler rather than an integrated manufacturer will exhibit higher levels of intermediates and final goods import. These affiliates are also less likely to engage in substantial (adaptive) R\&D. Some previous empirical studies have found a negative correlation between the reliance on imports and affiliate R\&D [Odagiri and Yasuda (1996), Zejan (1990)]. We control for possible differences in manufacturing and distribution roles by including IMPORT, the ratio of total imports to sales of the affiliate.

Finally, we include a set of controls for industry and location. Various characteristics related to the industry affect the need to perform $\mathrm{R} \& \mathrm{D}$ abroad: the maturity of products, the degree of product differentiation and international differences in consumer tastes, the degree of reliance on science and basic research, the existence of multiples centers of excellence and the scope for technological learning abroad, and government regulations which vary by industry (for instance regulations on clinical trials commonly in place in the pharmaceutical industry). Locational characteristics such as the size of the market, specific regulations requiring product adaptation, the available technological capabilities and excellence of the science base, and the degree of intellectual property rights protection available will also have a major impact on R\&D intensity of affiliates [e.g. Kumar (1996), Hakanson (1992)]. Not all these influences are easily quantifiable and controlled for in a set of independent variables. Since the focus of the present study is on parent and affiliate characteristics, we control for industry and locational factors by including a set of industry and country dummies. We distinguish fifteen industries and seventeen countries or regions. For all countries in which more than five affiliates were present a separate dummy was included.

\section{RESULTS}

The results of the Tobit model are presented in Table 3. The model generally performs well: the pseudo $\mathrm{R}^{2}$ of 0.32 is rather high for Tobit models with substantial censoring. ${ }^{16}$ The hypotheses on parent firm experience and internationalization (Hypotheses 1 and 2) are however not confirmed. P_EXPE has a counterintuitive negative sign but is insignificant with a very large estimated standard error. P_FDI has the expected positive sign but does not reach conventional significance thresholds. The results do support Hypothesis 3: operating experience in greenfield affiliates EXPE(GRE) has a positive and significant effect on the R\&D intensity of Japanese manufacturing affiliates. Operating experience under 
Japanese control in acquired affiliates EXPE(ACQ), has no significant effect, confirming a neutral (rather than negative) effect on R\&D intensity. The calculated marginal effect of EXPE(GRE) implies that seven more years operating experience causes a 0.26 percent points higher R\&D intensity. ${ }^{17}$ This is a relatively strong effect given the average $R \& D$ intensity of 0.85 percent. The results are in agreement with Hypothesis 4. Both ACQ(MAJ) and ACQ(MIN) are positive and significant. The size of the coefficients also confirms the importance of acquisitions for the expansion of Japanese R\&D abroad. An acquired affiliate has a 1.2 (majority acquisition) or 1.1 (minority acquisitions) percent points higher R\&D intensity than a wholly owned greenfield affiliate. The estimated coefficients imply that it would take a greenfield affiliate more than 32 years to reach the same level of R\&D intensity as acquired affiliates. This order of magnitude is consistent with the notion that access to the R\&D capabilities of the foreign firms has been an important motivation for Japanese firms' acquisitions. Hypothesis 5 is also largely confirmed by the empirical results. The coefficient for majority owned joint ventures is positive as hypothesized but not significant. In sharp contrast, the coefficient of the minority joint venture dummy JV(MIN) is positive and highly significant, and the impact effect is as large as that for acquisitions. The cross term of $\mathrm{P}_{-} \mathrm{R} \& \mathrm{D}$ and JV(MIN) is negative and significant, confirming that Japanese firms with strong R\&D capabilities are likely to enter into technology intensive minority owned joint ventures. The coefficients imply that non-majority owned joint ventures have lower R\&D intensity than wholly owned greenfield affiliates if parent firm R\&D intensity exceeds 8.5 percent. The positive and significant effect of EXPORT confirms that export oriented affiliates have greater R\&D responsibilities (Hypothesis 6). The impact effects show that an affiliate exporting 50 percent of its output has a 0.4 percent point higher $R \& D$ intensity than an affiliate with a purely local market franchise.

Among the control variables, $P_{-}$R\&D has a positive and significant effect on the $R \& D$ intensity of foreign affiliates. If the firm's line of business is R\&D intensive this is also reflected in the $R \& D$ intensity of affiliate operations. The marginal effect of $P_{-} R \& D$ does not indicate that this effect is very large effect, though: a one percent point increase in the parent's R\&D ratio leads to a 0.07 percent point increase in affiliate $R \& D$ intensity. Affiliate SIZE has a negative but insignificant effect on R\&D intensity. The import intensity of the affiliate, IMPORT, neither has a significant effect. The industry dummies show that R\&D intensity is significantly higher in chemicals, rubber and tires, and communication and computers, compared with the textile industry (the omitted dummy variable). The country dummies explain a substantial additional share of the variation in $R \& D$ intensity across 
affiliates. With Thailand as the reference group, the highest coefficients are estimated for the United Kingdom, North America, and other Western European countries, followed by Germany, Brazil and Taiwan. The lowest coefficients are for China, Indonesia, and perhaps surprisingly, Hong Kong.

\section{DISCUSSION}

We could not find confirmation of Hypotheses 1 and 2 related to parent firm internationalization and overseas experience. The insignificance of the two variables is not caused by multicollinearity: their correlation coefficient is only 0.09 and including internationalization or experience separately did not change the results. Although there is a stronger correlation between P_EXPE with P_R\&D (a correlation coefficient of 0.24), ${ }^{18}$ exclusion of P_EXPE neither changed the results. A linear or quadratic specification of P_EXPE gave insignificant results as well. One possible explanation for these findings is that it is primarily the geographic dispersion of productive assets and experience in operating an overseas manufacturing network in developed countries that facilitates the internationalization of R\&D. It is in developed countries where local R\&D capabilities and centers of excellence are concentrated and where coordination of a network of manufacturing plants with more decentralized R\&D functions can improve the firm's technological capabilities. We therefore tested a narrower formulation of Hypotheses 1 and 2 by only including the size of productive assets in developed countries relative to assets in Japan, P_FDI(DEV), and experience in operating manufacturing plants in developed countries, P_EXPE(DEV). The results are shown in Table 4. Although P_EXPE(DEV) remains insignificant with the wrong sign, $\mathrm{P}_{-}$FDI(DEV) has the expected positive sign and is significant the 5 percent level. The other empirical results are unaffected. Hence, firms that have decentralized responsibility for manufacturing to developed countries are more likely to decentralize R\&D responsibilities in overseas affiliates. If we can take the weight of manufacturing activities in developed countries as an indicator of parent firm's attitude with respect to centralized coordination, this can be taken as a partial confirmation of Hypothesis 1. On the other hand, the results suggest that the role of cumulative learning in overseas $R \& D$ is limited to the affiliate level and does not apply firm-wide, rejecting Hypothesis 2. Some further examination of the latter result appears to point again into the direction of an influence of acquisitive strategies at the wider firm-level. Within the sample of affiliates located in industrialized countries, parents of acquired affiliates exhibit much higher levels of 
investment in developed countries: the mean of P_FDI(DEV) is 15.1 for acquired affiliates and 9.5 for greenfield affiliates, and the correlation coefficient between a dummy for 'acquired affiliate' [ACQ(MIN)+ACQ(MAJ)] and P_FDI(DEV) is 0.18 and significant. This suggests that firms that have built up substantial manufacturing capabilities in developed countries have often done this by acquiring local firms. It is this expansion abroad through external growth, which allows these firms to avoid the time-consuming process of developing overseas R\&D capabilities through overseas experience. Indeed, there is some evidence in the data that parents of acquired affiliates entered developed countries later and have less experience in operating manufacturing plants in these countries: the correlation coefficient between the dummy for 'acquired affiliate' and parent firm experience P_EXPE(DEV) is 0.10 . Hence, the role of acquisitive strategies in the internationalization of Japanese firms may at least partly explain why we do not find a systematic effect of internationalization experience on overseas R\&D. ${ }^{19}$

Our findings show that at the affiliate level, the development in $R \& D$ operations in acquired affiliates is fundamentally different from the evolution of R\&D in greenfield affiliates. There is no evidence of a gradual increase in $R \& D$ responsibilities in acquired affiliates, but we neither find evidence of a systematic decline in R\&D intensity after the acquisition as suggested by Hitt et al (1991). One explanation is that a reorganization of R\&D after acquisition does involve a reduction in $\mathrm{R} \& \mathrm{D}$ spending on existing projects, but that this decline is only temporary until R\&D operations are assigned new tasks. Another possibility is that acquisitions often involve a reduced motivation among $R \& D$ personnel and an increase in personnel turnover, negatively affecting the performance of $R \& D$ rather than the level of R\&D spending. This would be consistent with a finding of reduced patent output in acquired affiliates after acquisition in Belderbos (1999). If one considers patents as intermediate outputs of the $R \& D$ process, then a decline in patent output combined with a level $R \& D$ expenditure indicates a decline in $\mathrm{R} \& \mathrm{D}$ productivity. This of course remains rather speculative. The post-acquisitions organization of $R \& D$ in acquired affiliates can only be uncovered through a longitudinal analysis, which unfortunately cannot be performed with the data at hand.

The results demonstrate the importance of acquisitions in the internationalisation of Japanese firms' R\&D. Although a limitation of our study is that we cannot observe the purpose of acquisitions directly, there is a strong suggestion that Japanese firms, given their relatively small $R \& D$ presence abroad, have actively acquired overseas firms in order to get access to foreign technology and in order to build up overseas R\&D capabilities at a faster 
pace. However, as discussed above, the fact that a firm acquires control over foreign affiliates with substantial R\&D expenditures does not provide information on the performance of these overseas R\&D activities. The literature on mergers and acquisitions has described a great number of pitfalls inherent to the management of post-acquisition operations, in particular the difficulties to integrate local learning capabilities into the global network of the acquiring firm [e.g. Hakanson (1995)]. A major and still open question is how successful external growth strategies of Japanese firms have been in creating an effective network of overseas $R \& D$ capabilities. More empirical research is needed on the managerial aspects of Japanese acquisitions of R\&D intensive foreign firms and the post-acquisition productivity of R\&D. ${ }^{20}$

A related issue concerns the developments in foreign R\&D activities after 1992 and the question whether the reliance on external growth has continued. There is evidence that Japanese acquisitions were strongly concentrated in the late 1980s and early 1990s when financial conditions related to the Japanese 'bubble economy' created extremely low opportunity costs for such investments. ${ }^{21}$ It is possible that the later 1990s have shown a renewed emphasis on organic growth of overseas operations, and overseas R\&D in particular. A limitation of our study is a restriction of the analysis to a cross section of affiliates in 1993 and the associated relatively modest amount of overseas R\&D expenditure covered. Extension of the present study to R\&D activities in the second half of the 1990s would shed light on the dynamics of R\&D internationalization. We hope to be able to examine the results of MITI's Sixth Basic Survey on foreign direct investment for the fiscal year ending March 1996. The 1996 survey has the additional advantage that $R \& D$ reporting has become more accurate and substantial, which will help to the overcome the limitations of the present study.

\section{CONCLUSION}

Our analysis revealed marked differences in $R \& D$ activities in foreign affiliates depending on ownership and entry mode. More than half of total R\&D is performed in affiliates in which Japanese firm have acquired a majority or minority ownership. Acquired affiliates have substantially and significantly higher $R \& D$ intensities than wholly owned and majority owned greenfield affiliates. Minority owned joint ventures play a specific role in the R\&D internationalisation process. Such ventures have a high R\&D intensity if the Japanese parent firm lacks important technological capabilities, but lower than average R\&D intensity if the parent firm is $R \& D$ intensive itself. This is consistent with the use by Japanese firms of 
minority ventures to get access to overseas technological know how. It also supports the hypothesis based on transaction cost theory that R\&D intensive firms are less likely to devote R\&D resources to ventures in which they do not have management control. Affiliates with a geographic mandate greater than the country of investment exhibit higher R\&D intensities, indicating that they have been assigned more substantial R\&D responsibilities, extending beyond from adoption and adaptation to new development for regional and world markets. The R\&D intensity of greenfield affiliates increases with operating experience, consistent with the view that foreign $R \& D$ is a process in which cumulative learning plays an important role. This growth in R\&D in greenfield affiliates is relatively small compared to the impact effect of acquisitions, for which a pattern of incremental growth in $R \& D$ is not observed. Firms that invested more in a decentralized network of manufacturing affiliates in developed countries are more likely to assign greater R\&D responsibilities to their overseas affiliates. On the other hand, an effect of parent firm experience in operating a network of overseas manufacturing affiliates on the R\&D intensity of their affiliates could not be established. This could suggest that learning effects are more affiliate-specific than firm-wide, while it may also be partly explained by the presence of acquisitive firms that have more recently expanded manufacturing and $R \& D$ activities in developed countries.

The results indicate that access to technology has been an important motivation for Japanese foreign direct investment and R\&D abroad. They provide further evidence [Penner Hahn (1998), Belderbos (1999), Grandstrand (1999)] that Japanese firms, as 'latecomers' in the internationalization of $\mathrm{R} \& \mathrm{D}$, have often adopted a strategy of external and collaborative R\&D growth abroad. This enables a faster build up of overseas R\&D capabilities than possible through internal growth and cumulative learning in a network of greenfield $R \& D$ sites. However, further research on the post-acquisition integration and performance of foreign $R \& D$ activities will be necessary to examine whether such strategies have been sustained and if they have been successful in creating a coherent and effective overseas R\&D network.

\section{References}

Almeida, Paul, 1996, Knowledge Sourcing by Foreign Multinationals: Patent Citation Analysis in the U.S. Semiconductor Industry, Strategic Management Journal, 17 (winter), $155-156$. 
Bartlett, Christopher A. and Sumantra Ghoshal, 1991, Managing Innovation in the Transnational Corporation, in: Christopher A Bartlet, Yves Doz and Gunnar Hedlund, eds., 1991, Managing the Global Firm, London and New york: Routledge.

Bartlett, C.A. and S. Ghoshal, 1989, Management Across Borders: The Transnational Solution, Harvard Business School Press, Boston, MA.

Behrman, Jack N. and William A. Fischer, 1980, Overseas R\&D Activities of Transnational Companies, Oelgeschlager, Cambridge, MA.

Belderbos, Rene A., 1997, Japanese Electronics Multinationals and Strategic Trade Policies, Oxford University Press, Oxford.

Belderbos, Rene A., 1999, Overseas Innovations by Japanese Firms: An Analysis of Patent and Subsidiary Data, Institute of Innovation Research Working Paper WP \#99-1, Hitotsubashi University, Tokyo, forthcoming in: Research Policy.

Belderbos, Rene A., Giovanni Capannelli and Kyoji Fukao, 1999, Local Procurement by Japanese Manufacturing Affiliates Abroad, Paper presented at the Seventh Sorbonne International Conference on Multinational Firm Strategies, University of Paris I, June 1718, 1999.

Belderbos, René A., and Leo Sleuwaegen, 1996, Japanese Firms and the Decision to Invest Abroad: Industrial Groups and Regional Core Networks, Review of Economics and Statistics, 78, 214-220.

Cantwell, J., 1991, The International Agglomeration of R\&D, in Casson, M. (eds.), Global Research Strategy and International Competitiveness, (Oxford, Basil Blackwell Limited)

Capron, Laurence, Pierre Dussauge, and Will Mitchell, 1998, Resource Deployment Following Horizontal Acquisitions in Europe and North America, 1988-1992, Strategic Management Journal, 19, 631-661.

Casson, Mark, ed., 1991, Global Research and Strategy and International Competitiveness, Basil Blackwell, Oxford and Cambridge, MA.

Chakrabarti, Alok, Jürgen Hauschildt, and Christian Süverkrup, 1994, Doet it Pay to Acquire Technological Firms? R\&D Management, 24 (1), 47-56.

Caves, Richard E., 1995, Multinational Enterprise and Economic Analysis, second edition (MIT Press, Cambridge).

Cheng, J.L. C. and D. S. Bolon, 1993, The Management of Multinational R\&D: A Neglected Topic in International Business Research, Journal of International Business Studies, 24 (1), 1-18.

Cohen, Wesley M., and Steven Klepper, 1996, A Reprise of Size and R\&D, Economic Journal, 106, 925-951.

Collis, D. J., 1991, A Resource-Based Analysis of Global Competition: The Case of the Bearings Industry, Strategic Management Journal, vol. 12, pp. 49-68.

DeMeyer, Arnaud, 1997, Management of International R\&D Operations, in: Lawrence H. Wortzel and Heidi Vernon-Wortzel, eds. Strategic Management in a Global Economy, John Wiley, Chichester, 419-430.

DeMeyer, Arnaud, and A. Mizushima, 1989, Global R\&D Management, R\&D Management, 19 (2), 135-146.

Duysters, G. and J. Hagedoorn, 1996, Internationalization of corporate technology through strategic partnering: an empirical investigation, Research Policy, Vol 25, 1-22

Florida, R., 1997 The globalization of R\&D: results of a survey of foreign -affiliated R\&D laboratories in the USA, Research Policy, 26, 85-103.

Fors, Gunnar, 1996, Utilization of R\&D Results in the Home and Foreign Plants of Multinationals, Journal of Industrial Economics, 45(3), 341-58. 
Fors, Gunnar, 1998, Locating R\&D Abroad: The Role of Adaptation and KnowledgeSeeking, in: Pontus Braunerhjelm and Karolina Ekholm, eds., The Geography of Multinational Firms, Kluwer Academic Publishers, Dordrecht.

Freeman, Christopher, 1987, Technology Policy and Economic Performance: Lessons From Japan, Pinter Publishers, London.

Fruin, Mark, 1992, The Japanese Enterprise System, Oxford University Press, Oxford.

Gassmann, Oliver and Maximilian von Zedtwitz, 1999, New concepts and trends in international R\&D organization, Research Policy, 28 (2-3), 231-250.

Gatignon, Hubert, and Erin Anderson, 1988, The Multinational Corporation's Degree of Control over Foreign Subsidiaries: An Empirical Test of a Transaction Cost Explanation, Journal of Law, Economics, and Organization, 4 (2), 305-336.

Gerybadze, Alexander and Guido Reger, 1999, Globalization of R\&D: recent changes in the management of innovation in transnational corporations, Research Policy, 28 (2-3), 251274.

Ghoshal, Sumantra, and Christopher Bartlett, 1988, Creation, Adoption, and Diffusion of Innovations by Subsidiaries of Multinational Companies, Journal of International Business Studies, 19 (3), 365-388.

Granstrand, Ove, 1999, Internationalization of corporate R\&D: a study of Japanese and Swedish corporations, Research Policy, (28) 2-3, 275-302.

Gomes-Cassares, Benjamin, 1989, Ownership Structures of Foreign Subsidiaries: Theory and Evidence, Journal of Economic Behavior and Organization, 11, 1-25.

Grandstand, O., and S. Sjolander, 1990, The Acquisition of Technology and Small Firms by Large Firms, Journal of Economic Behaviour and Organization, 13, 367-386.

Granstrand, Ove, Lars Hakanson, and Sören Sjölander, 1993, Internationalization of R\&D: A Survey of Some Recent Research, Research Policy, 22, 413-430.

Greene, Wiliam H., 1997, Econometric Analysis, Prentice Hall, London.

Greene, William H., 1997, LIMDEP Version 7.0: User's Manual and Reference Guide, Econometric Software Inc, Bellport, NY.

Hakanson, L. and R. Nobel, 1993a, Foreign research and development in Swedish multinationals, Research Policy, 22, 373-396

Hakanson, L. and R. Nobel, 1993b, Determinants of foreign R\&D in Swedish multinationals, Research Policy, 22, 397-411

Hakanson, L., 1995, Learning through Acquisitions, International Studies of Management and Organization, 25, 121-138, 152-155.

Hakanson, Lars, 1992, Locational Determinants of Foreign R\&D in Swedish Multinationals, in: Ove Granstrand, Lars Hakanson, and Soren Sjolander, eds, Technology Mangement and International Business, Internationalization of $R \& D$ and Technology, John Wiley and Sons, Chichester, 97-115.

Hall, Bronwyn, 1988, The Effect of Takeover Activity on Corporate Research and Development, in: Alan J. Auerbach, ed., Corporate Takeovers: Causes and Consequences, NBER and University of Chicago Press, Chicago and London.

Hennart, Jean-François, 1991, The Transaction Costs Theory of Joint Ventures: An Empirical Study of Japanese Subsidiaries in the United States, Management Science, 37, 483-497.

Hennart, Jean-François, Thomas Roehl, and Dixie S. Zietlow, 1999, 'Trojan Horse' or 'Workhorse'? The Evolution of U.S. - Japan Joint Ventures in the United States, Strategic Management Journal, 20, 15-29.

Hirschey, Robert C., and Richard E. Caves, 1981, Internationalisation of Research and Transfer of Technology by Multinational Enterprises, Oxford Bulletin of Economics and Statistics, 42, 115-130. 
Hitt, Michael A., Robert E. Hoskisson, R. Duane Ireland, and Jeffrey S. Harrisson, 1991, Effects of Acquisitions on R\&D Inputs and Outputs, Academy of Management Journal, 34 (3), 693-706.

Jaffe, Adam, Manuel Trajtenberg, and Rebecca Henderson, 1993, Geographic Localization of Knowledge Spillovers as Evidenced by Patent Citations, Quarterly Journal of Economics, 63, 577-598.

Kenney, M. and R. Florida, 1994, The organization and geography of Japanese R\&D: results from a survey of Japanese electronics and biotechnology firms, Research Policy, 23, 305323

Kester, Carl, 1991, Japanese Takeovers, Harvard Business School Press, Boston, MA.

Kogut, B., and Chang, S.J., 1991, Technological Capabilities and Japanese Foreign Direct Investment in the United States, Review of Economics and Statistics, 3, 400-413.

Kuemmerle, Walter, 1997, Building Effective R\&D Capabilities Abroad, Harvard Business Review, March-April 1997, 61-70.

Kuemmerle, Walter, 1998, Optimal Scale for Research and Development in Foreign Environments: An Investigation into Size and Performance of Research and Development Laboratories Abroad, Research Policy, 27 (2), 111-26.

Kuemmerle, Walter, 1999, The Drivers of Foreign Direct Investment into Research and Development: An Empirical Investigation, Journal of International Business Studies, 30 (1), 1-24.

Kumar, Nagesh, 1996, Intellectual Property Protection, Market Orientation, and Location of Overseas R\&D Activities by Multinational Enterprises, World Development, 24 (4), 673688.

Lall, S., 1979, International Allocation of Research Activity by US Multinationals, Oxford Bulletin of Economics and Statistics, 41, 313-331

Mansfield, Edwin, and Anthony Romeo, 1980, Technology Transfer to Overseas Subsidiaries of US-Based Firms, Quarterly Journal of Economics, 737-750.

Ministry of International Trade and Industry (MITI), 1994, Kaigai Toushi Tokei Souran (Basic Survey on Foreign Direct Investment), Okurashou Insatsukyoku, Tokyo.

Mutinelli, Marco, and Lucia Piscitello, 1998, The Entry Mode Choice of MNEs: An Evolutionary Approach, Research Policy, 27, 491-506.

Nobel, Robert, and Julian Birkinshaw, 1998, Innovation in Multinational Corporations: Control and Communication Patterns in International R\&D Operations, Strategic Management Journal, 19, 479-496.

Odagiri, Hiroyuki, and Hideto Yasuda, 1996, The Determinants of Overseas R\&D by Japanese Firms: An Empirical Study at the Industry and Company Levels, Research Policy, 25, 1059-1079.

Odagiri, Hiroyuki, and Akira Goto, 1993, The Japanese System of Innovation: Past, Present, and Future, in: Richard R. Nelson, ed., National Innovation Systems, Oxford University Press, Oxford, 76-114.

Papanastassiou, Marina, and Robert D. Pearce, 1994, The Internationalisation of Research and Development by Japanese Enterprises, $R \& D$ Management, 24, 155-165.

Patel, P. (1996) Are large firms internationalizing the generation of technology? Some new evidence, IEEE Transactions on Engineering Management, 43(1), 41-47

Patel, Pari, 1995, Localized Production of Technology for Global Market, Cambridge Journal of Economics, 19, 141-153.

Patel, Pari, and Keith Pavitt, 1991, Large Firms in the Production of the World's Technology: an Important Case of 'Non-Globalization', Journal of International Business Studies, 22, $1-22$. 
Pearce, Robert D., 1989, The Internationalisation of Research and Development by Multinational Enterprises, Macmillan, Basingstoke and London.

Pearce, Robert D., and Satwinder Singh, 1990, The Internationalisation of Research and Development by Multinational Enterprises: A Firm-Level Analysis of Determinants, Discussion Papers in International Investment and Business Studies Serie B, Vol III, No 145, University of Reading.

Penner-Hahn, Joan D., 1998, Firm and Environmental Influences on the Mode and Sequence of Foreign Research and Development Activities, Strategic Management Journal 19, 149168.

Perrino, Albert C., and James W. Tipping, 1991, Global Management of Technology: a Study of 16 Multinationals in the USA, Europe and Japan, Technology Analysis and Strategic Management, 3(1), 87-98.

Porter, Michael E., 1990, The Competitive Advantage of Nations, The Free Press, New York.

Ramachandran, Vijaya, 1993, Technology Transfer, Firm Ownership, and Investment in Human Capital, Review of Economics and Statistics 75, 664-70.

Veall, Michael J., and Klaus F. Zimmermann, Goodness of Fit Measures in the Tobit Model, Oxford Bulletin of Economics and Statistics, 56 (4), 485-499.

Vernon, Raymond, 1979, The Product Cycle Hypothesis in a New International Environment, Oxford Bulletin of Economics and Statistics, 41, 255-267.

Vonortas, Nicholas S., 1997, Research Joint Ventures in the United States, Research Policy, 26, 577-595.

Wakasugi, Ryuhei, 1992, Why are Japanese Firms So Innovative in Engineering Technology, Research Policy, 21 (1), 1-12.

Westney, D. Eleanor, 1994, The Evolution of Japan's Industrial Research and Development, in: Masahiko Aoki and Ronald Dore, eds. The Japanese firm: The sources of competitive strength,. Oxford University Press, Oxford and New York, 154-177.

Zejan, Mario C., 1990, R\&D Activities in Affiliates of Swedish Multinational Enterprises, Scandinavian Journal of Economics, 92 (3), 487-500. 
Table 1. Number of Affiliates, $R \& D$ Expenditure and $R \& D$ intensity by Industry, Region, and Entry Mode and Ownership Industry

\# affiliates

Food

Textiles

building materials

Chemicals

Pharmaceuticals

rubber and tires

Metals

general machinery

Electrical machinery

home electrical appliances

audio and video equipment

Electronic parts

other electronic equipment

Computers and communications eq.

Transport machinery

Precision machinery

other industries

All

Region

North America

Western Europe

Asian NIEs

Asean and China

Other countries

Entry Mode and Ownership

Wholly owned greenfield

Majority owned joint ventures

Non-majority owned joint ventures

Majority stake acquisitions

Minority stake acquisitions

19

23

19

52

16

10

43

41

18

21

13

29

18

10

73

10

19

434

\# affiliates

119

45

123

102

45

\# affiliates

148

89

103

43

51
R\&D/Sales (\%)

0.59

0.29

0.16

1.30

2.37

3.01

0.48

0.61

0.07

0.43

1.22

0.71

1.77

1.85

0.66

1.85

0.54

0.85

R\&D/Sales (\%)

1.39

1.70

0.70

0.22

0.43

R\&D/Sales (\%)

0.75

0.66

0.53

2.15

1.04

$\begin{array}{rr}\text { R\&D (mln Yen) } & \text { \% } \\ 234 & 0.8 \\ 133 & 0.4 \\ 97 & 0.3 \\ 2062 & 6.8 \\ 2479 & 8.1 \\ 7428 & 24.4 \\ 533 & 1.7 \\ 2832 & 9.3 \\ 62 & 0.2 \\ 1202 & 3.9 \\ 664 & 2.2 \\ 2733 & 9.0 \\ 1215 & 4.0 \\ 3682 & 12.1 \\ 4263 & 14.0 \\ 715 & 2.3 \\ 148 & 0.5 \\ 30482 & 100.0\end{array}$

R\&D (mln Yen) \%

$15626 \quad 51.3$

$9146 \quad 30.0$

$3813 \quad 12.5$

$487 \quad 1.6$

$1410 \quad 4.6$

$\begin{array}{rr}\text { R\&D (mln Yen) } & \text { \% } \\ 9662 & 31.7 \\ 1358 & 4.5 \\ 2510 & 8.2 \\ 11825 & 38.8 \\ 5127 & 16.8\end{array}$


Table 2: Means, Standard Deviations, and Description of Variables

\begin{tabular}{|c|c|}
\hline Variable & Description \\
\hline R\&DINT & Affiliate's $\mathrm{R} \& \mathrm{D} /$ sales ratio \\
\hline P_EXPE & $\begin{array}{l}\text { Logarithm of parent firm's years since establishment of first } \\
\text { manufacturing affiliate abroad }\end{array}$ \\
\hline P_EXPE(DEV) & $\begin{array}{l}\text { Logarithm of parent firm's years since establishment of first } \\
\text { manufacturing affiliate in US or Western Europe }\end{array}$ \\
\hline P_FDI & $\begin{array}{l}\text { Parent firm's ratio of total assets in overseas manufacturing affiliates } \\
\text { over assets in Japan }(\%)\end{array}$ \\
\hline P_FDI(DEV) & $\begin{array}{l}\text { Parent firm's ratio of total assets in US and EU manufacturing affiliates } \\
\text { over assets in Japan (\%) }\end{array}$ \\
\hline $\operatorname{EXPE}(\mathrm{GR})$ & Logarithm of greenfield affiliate's years since start operations +1 \\
\hline EXPE(ACQ) & Logarithm of acquired affiliate's years since acquisition +1 \\
\hline $\mathrm{ACQ}(\mathrm{MAJ})$ & Majority stake acquisition $(>50 \%)$ \\
\hline $\mathrm{ACQ}(\mathrm{MIN})$ & Minority stake acquisition $(<=50 \%)$ \\
\hline JV(MAJ) & Majority owned joint venture $(>50 \%,<95 \%)$ \\
\hline JV(MIN) & Non-majority owned joint venture $(<=50 \%)$ \\
\hline WHOLLY* & Wholly $(>95 \%$ owned greenfield establishment \\
\hline P_R\&D x JV(MIN) & cross effect $\mathrm{P} \_\mathrm{R} \& \mathrm{D}$ and $\mathrm{JV}(\mathrm{MIN})$ \\
\hline EXPORT & affiliate's export to sales ratio $(\%)$ \\
\hline IMPORT & affiliate's ratio import to sales ratio $(\%)$ \\
\hline P_R\&D & parent firm $\mathrm{R} \& \mathrm{D} /$ sales ratio $(\%)$ \\
\hline SIZE & affiliate's sales (bln Yen) \\
\hline FOOD & food \\
\hline TEXT* & textiles \\
\hline BUILD & building materials \\
\hline CHEM & chemicals \\
\hline PHARM & pharmaceuticals \\
\hline RUBBER & rubber and tires \\
\hline METAL & metals \\
\hline $\mathrm{MACH}$ & general machinery \\
\hline EMACH & electrical machinery \\
\hline HOUSEH & home electrical appliances \\
\hline $\mathrm{AV}$ & audio and video equipment \\
\hline ELPART & electronic parts \\
\hline OTHELEC & other electronic equipment \\
\hline COMM & Computers and communications equipment \\
\hline TRANSP & transport machinery \\
\hline PRECIS & precision machinery \\
\hline OTHERS & other industries \\
\hline NAMERICA & USA and Canada \\
\hline UK & United Kingdom \\
\hline FRANCE & France \\
\hline GERMANY & Germany \\
\hline EU_OTHER & Other Western Europe \\
\hline OCEAN & Australia and New Zealand \\
\hline KOREA & South Korea \\
\hline TAIWAN & Taiwan \\
\hline HONGK & Hong Kong \\
\hline SINGA & Singapore \\
\hline MALAY & Malaysia \\
\hline THAIL * & Thailand \\
\hline INDON & Indonesia \\
\hline CHINA & China \\
\hline INDIA & India \\
\hline BRASI & Brasil \\
\hline OTHER & Other countries \\
\hline
\end{tabular}

Mean

0.85

2.89

1.92

16.65

7.74

1.81

0.42

0.10

0.12

0.21

0.24

0.34

0.94

31.34

57.67

4.14

7.74

0.04

0.05

0.04

0.12

0.04

0.02

0.10

0.09

0.04

0.05

0.03

0.07

0.04

0.02

0.17

0.02

0.04

0.27

0.03

0.02

0.01

0.04

0.02

0.08

0.13

0.01

0.05

0.06

0.10

0.04

0.02

0.02

0.03

0.04 
Table 3. Tobit Analysis of the R\&D Intensity of Foreign Affiliates I

$\begin{array}{lrllrr} & \text { coefficient } & \text { t-ratio } & & \text { coefficient } & \text { t-ratio } \\ \text { P_EXPE } & -0.04 & -0.12 & \text { P_R\&D } & 0.18 & 2.66 * * * \\ \text { P_FDI } & 0.01 & 1.13 & \text { IMPORT } & 0.00 & 0.38 \\ \text { EXPE(GR) } & 0.65 & 2.07 * * & \text { SIZE } & -0.02 & -1.46 \\ \text { EXPE(ACQ) } & 0.18 & 0.36 & & \\ \text { ACQ(MAJ) } & 2.93 & 2.30 * * & & \\ \text { ACQ(MIN) } & 2.68 & 2.16 * * & & \\ \text { JV(MAJ) } & 0.32 & 0.64 & & \\ \text { JV(MIN) } & 2.91 & 3.92 * * * & & \\ \text { P_R\&D x JV(MIN) } & -0.34 & -2.56 * * * & & \\ \text { EXPORT } & 0.02 & 3.58 * * * & \end{array}$

Constant and industry dummies:

\begin{tabular}{|c|c|c|c|c|c|}
\hline FOOD & 1.30 & 1.15 & NAMERICA & 3.80 & $5.18 * * *$ \\
\hline BUILD & -1.90 & -1.43 & UK & 4.04 & $3.87 * * *$ \\
\hline CHEM & 1.74 & $1.83 *$ & FRANCE & 2.01 & 1.48 \\
\hline PHARM & 1.80 & 1.48 & GERMANY & 2.69 & $1.90 *$ \\
\hline RUBBER & 2.78 & $2.10 * *$ & EU_OTHER & 3.22 & $3.28 * * *$ \\
\hline METAL & 0.10 & 0.10 & OCEAN & 1.48 & 1.02 \\
\hline $\mathrm{MACH}$ & 0.31 & 0.31 & KOREA & 1.72 & $2.11 * *$ \\
\hline EMACH & -0.96 & -0.75 & TAIWAN & 2.34 & $3.11 * * *$ \\
\hline HOUSEH & 1.22 & 1.07 & HONGK & -0.06 & -0.03 \\
\hline AV & 1.68 & 1.38 & SINGA & 1.01 & 1.04 \\
\hline EPARTS & 1.06 & 1.03 & MALAY & 0.91 & 1.02 \\
\hline OTHELEC & 1.46 & 1.19 & INDON & 0.15 & 0.13 \\
\hline COMM & 2.62 & $1.91 *$ & CHINA & -0.60 & -0.37 \\
\hline TRANSP & 0.80 & 0.84 & INDIA & 1.03 & 0.70 \\
\hline PRECIS & 1.22 & 0.86 & BRASI & 2.62 & $2.39 * *$ \\
\hline OTHERS & 0.56 & 0.50 & OTHER & 1.85 & $1.90 *$ \\
\hline CONSTANT & -7.41 & $-4.38 * * *$ & & & \\
\hline Loglikelihood & -638.0 & $* * *$ & & & \\
\hline Observations & 434 & & & & \\
\hline
\end{tabular}

Notes: $*, * *, * * *$ indicate statistical significance at the 10,5, and 1 percent level, respectively (two tailed tests). The omitted dummies are: wholly owned greenfield, textile industry, and Thailand. 
Table 4. Tobit Analysis of the R\&D Intensity of Foreign Affiliates II

$\begin{array}{lrllrr} & \text { coefficient } & \text { t-ratio } & & \text { coefficient } & \text { t-ratio } \\ \text { P_EXPE(DEV) } & -0.09 & -0.51 & \text { P_R\&D } & 0.17 & 2.56 * * * \\ \text { P_FDI(DEV) } & 0.03 & 1.97 * * & \text { IMPORT } & 0.00 & 0.43 \\ \text { EXPE(GR) } & 0.63 & 2.12 * * & \text { SIZE } & -0.02 & -1.63 \\ \text { EXPE(ACQ) } & 0.09 & 0.18 & & \\ \text { ACQ(MAJ) } & 2.99 & 2.35 * * & & \\ \text { ACQ(MIN) } & 2.85 & 2.31 * * & & \\ \text { JV(MAJ) } & 0.29 & 0.58 & & \\ \text { JV(MIN) } & 2.98 & 4.00 * * * & & \\ \text { P_R\&D x JV(MIN) } & -0.34 & -2.58 * * * & & \\ \text { EXPORT } & 0.02 & 3.74 * * * & \end{array}$

Constant and industry dummies:

Country dummies:

\begin{tabular}{|c|c|c|c|c|c|}
\hline FOOD & 1.05 & 0.96 & NAMERICA & 3.77 & $5.13 * * *$ \\
\hline BUILD & -2.40 & $-1.80 *$ & UK & 3.93 & $3.78 * * *$ \\
\hline CHEM & 1.53 & 1.63 & FRANCE & 1.88 & 1.38 \\
\hline PHARM & 1.58 & 1.33 & GERMANY & 2.60 & $1.84 *$ \\
\hline RUBBER & 1.76 & 1.22 & EU_OTHER & 3.21 & $3.27 * * *$ \\
\hline METAL & -0.14 & -0.14 & OCEAN & 1.62 & 1.12 \\
\hline $\mathrm{MACH}$ & 0.03 & 0.03 & KOREA & 1.69 & $2.10 * *$ \\
\hline EMACH & -1.09 & -0.86 & TAIWAN & 2.31 & $3.10 * * *$ \\
\hline HOUSEH & 1.06 & 0.95 & HONGK & 0.04 & 0.02 \\
\hline AV & 1.59 & 1.33 & SINGA & 1.05 & 1.09 \\
\hline EPARTS & 0.87 & 0.85 & MALAY & 0.89 & 1.00 \\
\hline OTHELEC & 1.30 & 1.10 & INDON & 0.13 & 0.11 \\
\hline COMM & 2.40 & $1.78 *$ & CHINA & -0.15 & -0.10 \\
\hline TRANSP & 0.44 & 0.47 & INDIA & 0.99 & 0.67 \\
\hline PRECIS & 0.98 & 0.71 & BRASI & 2.66 & $2.44 * *$ \\
\hline OTHERS & 0.32 & 0.29 & OTHER & 1.84 & $1.91 *$ \\
\hline CONSTANT & -7.12 & $-4.72 * * *$ & & & \\
\hline Loglikelihood & -636.7 & $* * *$ & & & \\
\hline Observations & 434 & & & & \\
\hline
\end{tabular}

Notes: $*, * *, * * *$ indicate statistical significance at the 10,5, and 1 percent level, respectively (two tailed tests). The omitted dummies are: wholly owned greenfield, textile industry, and Thailand. 
Appendix: Correlation Coefficients

\begin{tabular}{|c|c|c|c|c|c|c|c|c|c|c|c|c|c|c|c|c|}
\hline & R\&DINT & P_EXPE & $\begin{array}{r}P_{(\mathrm{EXPE})} \\
\text { (DEV) }\end{array}$ & P_FDI & $\begin{array}{l}P_{\text {_FDI }} \\
(\overline{D E V})\end{array}$ & $\begin{array}{r}\text { EXPE } \\
(\mathrm{GR})\end{array}$ & $\begin{array}{r}\text { EXPE } \\
(A C Q)\end{array}$ & $\begin{array}{r}\text { ACQ } \\
(\mathrm{MAJ})\end{array}$ & $\begin{array}{r}\text { ACQ } \\
(\mathrm{MIN})\end{array}$ & $\begin{array}{r}\text { JV } \\
(\mathrm{MIN})\end{array}$ & $\begin{array}{r}\mathrm{JV} \\
(\mathrm{MAJ})\end{array}$ & $\begin{array}{l}\text { P_R\&D x } \\
\text { JV(MIN) }\end{array}$ & IMPORT & EXPORT & P_R\&D & SIZE \\
\hline R\&DINT & 1.00 & & & & & & & & & & & & & & & \\
\hline P_EXPE & -0.08 & 1.00 & & & & & & & & & & & & & & \\
\hline P_EXPE(DEV) & 0.08 & 0.42 & 1.00 & & & & & & & & & & & & & \\
\hline P_FDI & 0.00 & 0.08 & 0.10 & 1.00 & & & & & & & & & & & & \\
\hline $\mathrm{P}_{-}^{-} \mathrm{FDI}(\mathrm{DEV})$ & 0.14 & 0.09 & 0.35 & 0.60 & 1.00 & & & & & & & & & & & \\
\hline EXPE(GR) & -0.13 & 0.24 & -0.03 & -0.15 & -0.21 & 1.00 & & & & & & & & & & \\
\hline EXPE(ACQ) & 0.13 & 0.04 & 0.05 & 0.18 & 0.25 & -0.77 & 1.00 & & & & & & & & & \\
\hline ACQ(MAJ) & 0.21 & -0.17 & 0.04 & 0.07 & 0.18 & -0.53 & 0.54 & 1.00 & & & & & & & & \\
\hline ACQ(MIN) & 0.03 & 0.08 & 0.04 & 0.13 & 0.12 & -0.58 & 0.66 & -0.12 & 1.00 & & & & & & & \\
\hline JV(MIN) & -0.09 & 0.07 & -0.09 & 0.00 & -0.12 & 0.27 & -0.27 & -0.18 & -0.20 & 1.00 & & & & & & \\
\hline JV(MAJ) & -0.05 & 0.04 & -0.01 & -0.04 & -0.01 & 0.22 & -0.24 & -0.17 & -0.19 & -0.28 & 1.00 & & & & & \\
\hline $\begin{array}{l}P_{J} R \& D x \\
J V(M I N)\end{array}$ & -0.07 & 0.16 & 0.07 & -0.04 & -0.10 & 0.21 & -0.20 & -0.14 & -0.16 & 0.77 & -0.22 & 1.00 & & & & \\
\hline IMPORT & -0.04 & -0.13 & -0.01 & -0.03 & 0.00 & -0.06 & -0.05 & 0.01 & -0.08 & -0.05 & 0.04 & 0.02 & 1.00 & & & \\
\hline EXPORT & 0.07 & -0.08 & -0.19 & 0.01 & -0.17 & 0.05 & -0.06 & -0.05 & -0.08 & -0.15 & 0.05 & -0.12 & 0.06 & 1.00 & & \\
\hline P_R\&D & 0.18 & 0.24 & 0.40 & -0.09 & 0.05 & 0.05 & 0.00 & 0.03 & -0.04 & -0.03 & -0.04 & 0.26 & 0.04 & -0.01 & 1.00 & \\
\hline SIZE & 0.01 & 0.04 & 0.18 & 0.13 & 0.26 & -0.06 & 0.13 & 0.12 & 0.00 & -0.01 & -0.10 & 0.03 & 0.18 & -0.07 & 0.23 & 1.00 \\
\hline
\end{tabular}

Note: industry and country dummy are excluded 


\section{ENDNOTES}

1 Bartlett and Ghoshal (1991) concluded this in a study of international R\&D management by Japanese electronics multinational Matsushita. A similar centralization focus was found in a more recent study of the organization of R\&D in Nissan and Nippon Steel [Gassmann and von Zedtwitz (1999)].

${ }^{2}$ Whereas empirical experience has shown that industry level results can often not be replicated in firm level studies [Cheng and Bolon (1993)].

3 The exception is a preliminary analysis in Belderbos (1997) using MITI survey data to examine R\&D expenditures in a small sample of Japanese electronics affiliates.

4 e.g. Hirschey and Caves (1981), Hewitt (1980), Lall (1979), Pearce (1989), Cantwell (1989), Casson (1991), Zejan (1990), Hakanson and Nobel (1993a, 1993b), Odagiri and Yasuda (1996), Belderbos (1997, 1999), Kuemmerle (1999). Pearce (1989), Grandstrand et al (1993) and Dunning (1994)] provide overviews of the literature.

${ }^{5}$ Findings in Von Brockdorf and Schmaul (1996) may illustrate this. German multinational firms that operated a centralized 'hub' model with centralized coordination of overseas R\&D perceived their R\&D management system to perform better than firms operating a 'network' model with more decentralized control and distributed research tasks.

${ }^{6}$ The first has also been coined 'demand side' motivation for overseas R\&D or 'home base exploiting' overseas R\&D, and the second 'supply side' motivation or 'home base augmenting' R\&D [e.g. Kuemmerle (1997), Odagiri and Yasuda (1996)].

${ }^{7}$ See Collis (1991) for evidence that administrative heritage has a major influence on internationalization strategy in the case of the bearing industry.

${ }^{8}$ Zejan (1990) however obtained a positive but insignificant coefficient for affiliate operating experience.

${ }^{9}$ Hennart et al. (1999) suggests that Japanese joint ventures in the United States established in the 1980s were set up to benefit from the US partner's technological capabilities by building up new R\&D resources, rather than to 'expropriate' existing knowledge possessed by the US partner.

${ }^{10}$ The same threshold value is used by the US Department of Commerce in its Benchmark Survey among US multinational firms.

${ }^{11}$ A common reason for non-response is that R\&D expenditures are not part of the affiliates' accounting system such that firms lack the necessary information to fill in the questionnaire. This problem is related to the lack of mandatory disclosure of R\&D figures in Japan and the absence of consolidated taxation.

12 The only difference is a 5 percent point higher share of North American affiliates in the sample, which is likely due a more established practice of $R \& D$ reporting there.

13 The high ratio in the rubber and tire industry appears due to the weight of two acquisitions of large tire manufacturer: Bridgestone's acquisition of Firestone of the US and Sumitomo Rubber's acquisition of Dunlop of France.

${ }^{14}$ Although in theory a two-limit Tobit model could also be used to allow for censoring at a maximum R\&D to sales ratio of one, R\&D intensities in practice never come near this threshold and right limit censoring does not occur. 
${ }^{15}$ To all experience variables the value one was added before taking the natural logarithm. EXPE(GR) has the value zero in case of acquired affiliates and $\operatorname{EXPE}(\mathrm{ACQ})$ is zero for greenfield affiliates.

${ }^{16}$ The pseudo- $\mathrm{R}^{2}$ measure used here is the one proposed by McFadden: 1- $\left(\right.$ LOGL $^{\mathrm{u}} / \mathrm{LOGL}^{\mathrm{r}}$ ) where LOGL ${ }^{\mathrm{u}}$ is the unrestricted loglikelihood of the full model and LOGL ${ }^{\mathrm{r}}$ the restricted loglikelihood of a restricted model with only the constant term included. Though not designed for Tobit models, McFadden's pseudo- $\mathrm{R}^{2}$ can be used to assess goodness of fit of Tobit models provided that the loglikelihoods of the models are negative. It is important to note that this pseudo- $\mathrm{R}^{2}$ cannot be compared with an $\mathrm{R}^{2}$ obtained in OLS regressions. The censoring in the Tobit model systematically biases the pseudo- $\mathrm{R}^{2}$ downwards. Veall and Zimmermann (1994) show that the pseudo- $\mathrm{R}^{2}$ of 0.30 in our Tobit model compares to an $\mathrm{R}^{2}$ of 0.65 in an OLS model, given the relatively high level of censoring in our data (roughly 50 percent).

17 The marginal effect in the conditional mean is calculated as 0.26 , which implies that a doubling of $\operatorname{EXPE}(G R)$ in the mean increases R\&D intensity by 0.26 percent points. The mean of $\operatorname{EXPE}(G R E)$ in the sample is seven years. This relatively low mean is due to the presence of acquired affiliates (which are assigned a zero value for greenfield operating experience) in the sample.

${ }^{18}$ Such a correlation is consistent with theory and evidence on the decision to invest abroad by multinational enterprise, [e.g. Caves (1995), Belderbos and Sleuwaegen (1996)].

${ }^{19}$ Unfortunately, we cannot examine the role of acquisitive strategies at the wider firm level in more detail, because we do not possess the detailed information on ownership for all the parent firms' overseas affiliates.

${ }^{20}$ Scattered evidence does not suggest that Japanese firms have been particularly successful in integrating acquired firms. This may be demonstrated by a number of divestments in the second half of the 1990s, such as Matsushita's sale of MCA and the sale of Silicon Systems (a specialized manufacturer of chips for disk drives) by TDK.

${ }^{21}$ E.g. Belderbos (1997), Kester (1993). Three quarters of the majority acquisitions in our sample took place in or after 1987. 